\title{
PEDAGOŠKI POTENCIJAL MUZEJA - MUZEJ KAO CENTAR OBRAZOVANJA I UČENJA
}

\author{
Aleksandra Milanović ${ }^{1}$ \\ Univerzitet u Nišu, Pedagoški fakultet u Vranju
}

\begin{abstract}
Apstrakt: U radu se analizira značaj muzejskih ustanova za vaspitno-obrazovni rad. Muzej, na prvi pogled viđen kao mesto za ispunjavanje slobodnog vremena, ima veliki značaj i doprinos za pedagoški rad kako sa mladim tako i sa starijim naraštajima. Najčešći vid odlaska u muzej jeste organizovana, vođena poseta grupe učenika od strane nastavnika, uglavnom nastavnika maternjeg jezika ili likovne kulture. U radu smo nastojali ukazati na značaj savremenih teorija o pedagoškom radu u muzeju (aktivno učenje, konstruktivna teorija, instruktivno-didaktička teorija, socijalno-konstruktivistička teorija, kritička teorija). Zatim smo približili konstruktivitički pristup muzejskom učenju. U drugom delu rada predstavili smo vidove pedagoškog rada u muzeju. Prvi vid pedagoškog rada u muzeju jesu izložbe. One su uvek organizovane prema određenoj tematici i sa određenim ciljem, gde nije strogo određeno na šta će posetilac najviše pažnje obratiti a gde se, sa druge strane, pruža veliki broj jedinstvenih doživljaja i iskustava. Izložba je savršeno mesto za povezivanje prošlosti i sadašnjosti, ukoliko je glavna odlika izložbe istorijski momenat. Takođe, idealan je način za komunikaciju posetioca sa izloženim muzejskim materijalom i diskusiju sa muzejskim osobljem, ali i ostalim posetiocima. Radionice, kao drugi vid edukativnog muzejskog rada, pružaju mogućnost za sticanje veština i interakciju sa ostalim članovima grupe. Nastojali smo ukazati i na značaj saradnje muzejskih ustanova sa školskim ustanovama svih nivoa, za koju je važna usklađenost muzejskog i školskog programa. Saradnja muzeja sa obrazovnim ustanovama doprinosi čitavom društvenom razvoju, ali i boljem i kvalitetnijem razvoju ličnosti posetilaca, najčešće dece.
\end{abstract}

Ključne reči: muzej, učenje, savremene teorije, konstruktivizam, izložbe, radionice, saradnja

\section{Uvod}

Zadatak muzeja je da pomaže učeniku da aktivno koristi stečene informacije, da stvori atmosferu koja će stimulisati aktivno učenje. Muzej je mesto za samovođeno, aktivno i radosno učenje, to je mesto za učenje i diskusiju (Navarro, 2012), ima

\footnotetext{
${ }^{1}$ aleksandrak@ucfak.ni.ac.rs
} 
zadatak da angažuje i provocira posetioca. Muzeji izazivaju uzbuđenje, zadržavaju dečiju pažnju, podstiču fizičku aktivnost i utiču na nivo i kvalitet dečijeg znanja i razvoja. Sa pojavom moderne tehnologije muzeji su pod još većim pristiskom da oblikom i sadržajem njihovih eksponata zadovolje potrebe posetioca. Omogućavaju da se slobodno vreme pored zabave koristi i za upoznavanje okruženja, da se informacionim resursima potpomogne formalno obrazovanje, olakšava učenje teških predmeta i podstiče decu na umetnost i dizajn. Sadašnji muzeji su daleko od tradicionalnog, interaktivni su, dinamični i omogućavaju posetiocu da stekne dublji uvid $\mathrm{u}$ informacije. U današnje vreme, nove tehnologije i mediji šire se kroz muzejsko okruženje. Muzeji su postali deo sofisticiranog kompjuterskog sveta, koriste se za umrežavanje i telekomunikaciju, koriste 3D obradu slika, interaktivnu komunikaciju (Bernard, 2001 prema Ciolfi et al., 2005).

Muzeji su pogodno mesto za rad na terenu od strane nastavnika, kao posrednika između deteta i muzejskog učenja. Nastavnicima je potrebno savetovanje, obuka i podrška za moguće načine učenja koje muzeji nude. Obrazovanje je jedna od ključnih uloga muzeja. Oni predstavljaju vredan resurs za nastavu, te tako učenici svih uzrasta mogu mnogo toga saznati u muzejima (Chee, 2003). Nude razne pedagoške aktivnosti namenjene deci svih školskih uzrasta kao i deci sa posebnim potrebama (Trskan, 2003), gde u ovom slučaju možemo svrstati i darovite učenike. Muzeji su bogata mesta za informalno i neformalno učenje (Davies, 2004).

Omogućavaju novim generacijama da uče na iskustvima i otkrićima prethodnih generacija i na taj način doprinose nauci, umetnosti i materijalnim dobrima. Poseta muzeju je psihološki potkovana poseta gde muzejski objekat, odnosno dela koja se mogu videti stvaraju prvi utisak kod posetioca. Osnovna funkcija muzeja je prikupljanje, snimanje i čuvanje prošlosti. Dakle, muzej ima polivalentnu funkciju, to je živi edukativni prostor koji je na raspolaganju posetiocima raznih uzrasta (Brajčić et al., 2013), ali i mogućnosti i interesovanja. Osnovna prednost muzeja je jednostavnost kao jedan od glavnih didaktičkih principa.

Muzeji informišu posetioce o istoriji, imaju obrazovne programe, najčešće služe za poboljšavanje iskustva i uživanje u kolekcijama od strane posetioca (Eddisford, 2009), dakle, muzej je institucija sa značajnom pedagoškom komunikacijom. Savršena muzejska praksa teži jačanju saradnje muzeja sa predškolskim i školskim ustanovama. Muzejskim sadržajima moguće je kreirati otvorene, fleksibilne i samoregulisane aktivnosti za decu (Kisovar Ivanda i Nenadić Bilan, 2015).

Muzeji su agenti društvenih promena odgovorni za socijalnu inkluziju i razvoj zajednice, podrška razvoju nauke i doživotnom učenju. U nekim muzejima programi su dobro organizovani tako da uključuju akreditovane kurseve, praktične radionice, organizovane posete, diskusije, predavanja i porodične događaje (Gibs et al., 2007). Muzej je mesto pogodno za sejanje „semena interesa” (Wellington, 1990, prema Clegg et al., 2006). Zato je muzej institucija koja može pomoći deci da nauče da uče samostalno, razmišljaju kritički i razvijaju svoje interese. Raspolažu obiljem različitosti, raznovrsnosti prirodnog okruženja i iskustvima, posetioci se posmatraju kao aktivni učesnici, naglasak je na ulozi posetioca a izložbama i programima teži se odgovoru na potrebe istog (Hooper-Greenhill \& Moussouri, 2000). 
Neophodno je da muzej kao centar obrazovanja i vaspitanja obuhvata rad muzejskog pedagoga, kustosa koji će se baviti obrazovnim radom, stalni sastav, zaštićen material, stalni katalog izložbi, usklađenost izložbi prema didaktičkim principima, adekvatne finansije, aktivno učešće muzejskog pedagoga u izradi koncepcija i postavljanju izložbi (Kanižaj, 1987). Muzejski pedagog je osoba koja vodi, organizuje izložbe, animira posetioce i na taj način doprinosi povećanju broja posetilaca. Pored tradicionalnog zadatka da prikuplja, štiti i istražuje muzejske predmete ima sve veći značaj za odnos sa javnošću i kao takav predstavlja jedan vid mas-medija (Cukrov, 2002).

Trozbi (Throsby, 2001 prema Kisovar Ivanda, 2009) muzej vidi kao ustanovu koja doprinosi javnoj raspravi o umetnosti, kulturi i društvu; pomaže određivanju identiteta u specifičnom i opštem smislu; podstiče kreativan napor i rad; trajno je otvoren za komunikaciju; muzejska baština ostaje budućim naraštajima; pruža obrazovne usluge (formalni i informlani karakter); povezuje sa drugim kulturama; Pruža članovima jednog društva osećaj zadovoljstva i zajedništva.

Stručni rad u muzeju deli se na dve celine: stručno-naučni rad i prosvetno-pedagoška uloga koja se odnosi na upotrebu znanja iz oblasti psihologije i pedagogije (Babić, 2009). Muzej svoj rad prezentuje kroz muzejske postavke, publikacije, muzejsko-pedagošku delatnost, muzejske propagande, predavanjima u saradnji sa školama (Morine, 1975). Služi zadovoljenju kulturnih potreba, to je sredina za kulturno kretanje. Ne treba ga videti kao pasivnu i statičnu ustanovu. Neposredno je uključen u nastavni proces i svojim radom doprinosi prenošenju estetskih, funkcionalnih, kulturnih značenja. Doprinosi humanizaciji učesnika, posetilaca (Stojanović, 1987). S obzirom na veliki obrazovni potencijal muzeja pomenuti autor izdvaja dva problema: Kako eksplicitno formulisati vaspitno-obrazovne ciljeve u skladu sa prirodom muzejske delatnosti; Kako od alternativnih oblika rada odabrati najuspešniji za ostvarenje ciljeva.

Gajić i Milutinović (2011: 174) konstruktivnu ulogu muzeja ističu kao vodeću. „Muzeji preuzimaju mesto za komunikaciju, obrazovanje, istraživanje, učenje, razvoj identiteta, podsticanje darovitosti kao i vrednovanje istorijskog i umetničkog nasleđa u sociokulturnim i edukativnim okvirima.“

Zadaci muzejskog posredovanja:

1. Definisati obrazovne sadržaje u skladu sa poslovanjem muzeja.

2. Programe razvijati i organizovati u skladu sa potrebama posetilaca.

3. Ponuditi mogućnost kulturnog obrazovanja svim posetiocima.

4. Ostvariti lične i medijske koncepte posredovanja.

5. Stvarati sliku prilagođenog i prijateljskog muzeja i omogućiti posetiocima da uživaju.

6. Uspostaviti veze između muzeja i drugih kulturnih i obrazovnih institucija.

7. Redovno vrednovati posredovanje radi provere učinkovitosti i osiguravanja kvaliteta posredovanja (Škarić, 2012).

Muzeji oživljavaju ljudsku istoriju, oslikavaju društveni život u određenom vremenu i prostoru, govore mnogo o kulturi i tradiciji, te se svim tim utiče na stvara- 
nje i prenošenje znanja i doživljaja neverbalnim putem (Pavlović i Lazarević, 2008). Maroević (1990) ističe da muzej kao posredni činilac između kulturne i prirodne baštine treba da tumači kvalitet integrisane prirodne i kulturne okoline na način koji je prihvatljiv svakom socijalnom sloju.

Možemo reći da je cilj rada zapravo bliže predstavljanje muzeja kao institucije od velikog značaja za razvoj i učenje svih generacija, naročito učenika na svim stupnjevima školovanja. Kao i ukazivanje na ulogu koju muzej, kao centar vaspitanja i obrazovanja, ima za pedagoški rad.

\section{Učenje u muzeju}

Muzeji su informalni centri za učenje inicirano radoznalošću, posmatranjem i samoaktivnošću. Odlika muzejskog učenja je eksperimentalna priroda učenja zasnovana na susretima sa stvarnim objektima. Učenje u muzeju pomaže proširivanju vidika, izaziva čuđenje, radoznalost, poziva na otkriće. Muzej je mesto sa visokim potencijalom za učenje putem otkrića. Objekti u muzeju ostavljaju prostora za poređenja, za formiranje hipoteza i diskusiju. Ovaj kognitivni aspekt učenja podržava i kognitivni i društveni razvoj dece. Ciljna grupa učenja u muzeju je mlađa generacija. Muzej budućnosti nastojaće da angažuje nove generacije posetilaca nudeći im širok spektar obrazovnih strategija uz omogućavanje aktivnog učenja i demonstraciju i primenu znanja, podstičući decu da uče iz igre i istraživanja (Brajčić et al., 2013; Weber, 2003).

Učenje u muzejima nije vođeno, nema instrukcija, nema autoriteta već je samousmereno, samomotivisano i doborovoljno. Akcenat je na procesu a ne na rezultatu učenja. Muzeji su pogodni za pronalaženje, istraživanje ideja, ishodi učenja nisu određeni unapred, a ključni elementi su stvaranje veze između poznatog i nepoznatog, sticanje autentičnog iskustva posmatranjem i manupulacijom realnim predmetima i doživljavanjem stvarnih fenomena (Hein, 1988, prema Milutinović, 2010). Učenje u muzeju uključuje gledanje, postavljanje pitanja, poređenja (Shepard, 1993, prema Brajčić et al., 2013). Borun i saradnici (Borun et al., 1996, prema: Isto) navode indikatore učenja u muzejima: postavljanje pitanja i davanje odgovora, razgovor o izložbi, fokusiranje na određeni deo izložbe, čitanje teksta koji opisuje posmatranu umetnost, učešće u raznim aktivnostima ili jednostavno posmatranje izloženog materijala. Osnovni elementi učenja su percepcija i memorija. Percepcija je uslovljena prethodnim iskustvom. Učenje zavisi od motivacije i stavova polaznika, od ranijih iskustava, kulturne pozadine - naročito kada govorimo o muzejskom učenju koje traži individualni napor i socijalno iskustvo (Hooper-Greenhil, 1999, prema HooperGreenhil \& Moussouri, 2000).

Hartinger (2001: 332, prema Weber, 2003) navodi tri tipa učenja putem otkrića, kao način učenja u muzejima. Učenje primerima - induktivno učenje gde učenici identifikuju karakteristike analizirajući prave i kontraprimere; učenje eksperimentima - razvoj znanja o pravilima i zakonima kao i razvoj samokontrole i učenje rešavanjem sporova. Bentli i Vots (Bentley \& Watts, 1994, prema Brajčić i sar. 2013) 
navode sopstvenu aktivnost i odgovornost za samoučenje, donošenje odluka i rešavanje problema, prenos znanja iz jednog konteksta u drugi, individualni i grupni rad, samovrednovanje, razumnost i kompetentnost u mnogim oblastima i osećaj zadovoljstva zbog samoučenja kao pokazatelje aktivnog učenja u muzeju:

Muzeji uključuju veliki broj filozofskih i praktičnih aspekata prilikom planiranja učenja. Uključuje učenje kao konstruktivni dijaloga a ne kao pasivno prenošenje informacija, daje primat učešću privilegovanih učesnika a ne stručnjacima, pravilno vrednuje značaj formalnog školskog programa i olakšava celoživotno učenje pružajući slobodu izbora (Hawkey, 2004).

Pozitivni ishodi muzejskog učenja su povećano znanje i razumevanje, razvoj novih veština i sposobnosti i inspiracija da nauče više i bolje. Važno je pri poseti muzeju praviti vezu sa onim što se tamo može videti, čuti, pročitati kako bi poseta bila učinkovita i kako bi dete dobilo želju da ponovo ode u muzej. Učenje u muzeju treba da se zasniva na primeni teorije učenja i uspešnih metoda rada sa polaznicima. Zasniva se na čvrstom držanju kulturnih, institucionalnih i ličnih pretpostavki muzejskog osoblja prema posetiocu. Obrazovna uloga uzeja priznata je od strane stručnjaka i javnosti. Učenje u muzejima i galerijama spada u informalno učenje ili učenje slobodnog izbora zasniva se, funkcioniše na zbirkama, izložbama u muzeju i fokusira se na konkretne materijalne stvari i kvalitativno je drugačije od učenja apstraktnih ideja iz knjiga (Hooper-Greenhill \& Moussouri, 2000). Učenje u muzeju je snažno iskustvo, dobrovoljno i samomotivisano, delimično kognitivno i ima snažnu afektivnu komponentu, utiče na stavove, interese, uverenja i vrednosti (Kisovar Ivanda, 2009).

Mogućnost učenja u muzeju zavisi od pozitivne okoline, recipročnih interakcija i zabavnog druženja dece i odraslih. Muzej je mesto za izgradnju zajednice koja uči. Kako bi se sticalo što kvalitetnije iskustvo potrebna je adekvatna prostorna organizacija, uspešno uređen muzejski prostor, uređen prostor za samostalna istraživanja, uređen prostor za igru i istraživanje u većim i manjim grupama, dobro pripremljeno muzejsko osoblje i treba voditi računa o fleksibilnoj organizaciji vremena za muzejsku posetu (Kuščević, 2015). Falk i Dirking (Falk \& Dierking, 1995 prema HooperGreenhil \& Moussouri, 2000) izdvajaju faktore procesa učenja: prethodno znanje i iskustvo, ojačavanje iskustva, motivacija i stavovi, kultura i okruženja, socijalno posredovanje, dizajn i prezentacija i fizičko podešavanje. Didaktička pravila kojih se valja držati prilikom učenja u muzeju jesu od bližeg ka daljem, od jednostavnijeg ka složenijem i od poznatog ka nepoznatom (Pavlović Lazarević, 2008).

Muzej posećuju ljudi sa različitim motivima, karakter učenja u muzeju je informalan i neformalan. Učenje se odvija bez prisile, u relaksiranom okruženju sa osećajem ugodnosti (Jelavić, 2014). Za uspešno muzejsko učenje potrebno je sadejstvo ličnog, društvenog i fizičkog aspekta. Učenje u muzeju vođeno je radoznalošću, željom za otkrivanje, slobodnim istraživanjem i deljenjem iskustva sa vršnjacima, porodicom i ostalim posetiocima. To su mesta za interakcijsko učenje, učenje aktivnostima - delovanjem i socijalnom saradnjom. Ova vrsta učenja je proizvod slobodne interakcije u slobodnom vremenu između posetioca i muzejske sredine (Milutinović, 2010). Počiva na spontanoj komunikaciji unutar vršnjačkih grupa, sa 
učiteljem koji vodi decu, sa muzejskim pedagogom, kustosom. Odvija se kroz dve vrste inetarkcija. Interakcija učenika i muzejskih izložbenih predmeta i artefekata i interakcija u muzejskom okruženju između učenika, ili između učenika i odraslih osoba (Kisovar Ivanda, 2014).

\section{Savremene teorijske osnove pedagoškog rada u muzeju}

Mogućnost učenja u muzeju treba da počiva na teoriji učenja i primeni uspešnih metoda u radu sa polaznicima na kulturnim, institucionalnim ili ličnim pretpostavkama osoblja muzeja. Postoji pet glavnih teorija učenja u muzejima (Gibs et al., 2007; Stroud, 2008): aktivno učenje, konstruktivna teorija, instruktivno-didaktička teorija, socijalno-konstruktivistička teorija i kritička teorija.

Aktivno učenje javlja se u naučnim muzejima 1970. g., te se nakon toga prenosi i na ostale vrste muzeja. Učenje će biti najbolje u opuštenoj, neformalnoj atmosferi. Učenje je zapravo istraga sa direktnim učešćem učesnika. Aktivno učenje ili učenje otkrićem najbolje se odvija u opuštenoj, neformalnoj atmosferi gde su nejasne granice između učenja i zabave. Učenje je proces istrage koji direktno uključuje polaznika kao aktivnog učesnika. Konstruktivistički pristup stavlja focus na učenika ne na sadržaj, te je u ovom pristupu učenje shvaćeno kao aktivan proces. Socijalno konstruktivistička teorija kaže da su muzeji mesta sa širokim fondom socijalnog, kulturnog, istorijskog i političkog znanja. Posetioci viđeno uklapaju u svoje dotadašnje iskustvo. Muzeji su mesta na kojima su socijalno, kulturno i političko znanje izgrađeni po dogovoru, posetioci usvajaju ponuđene informacije u skladu sa svojim identitetima i društvenim položajem. Pol, rasa, etnička pripadnost, seksualnost, religija, postaju presudni za tumačenje sadržaja. Znanje je podložno stalnim promenama i stalnim diskusijama. Ovaj pristup podstiče učenika da se svojim predlozima direktno uključuje u organizovanje izložbi. Pored učenja fokusiranog na fizičko okruženje postoji i učenje u skladu sa društvenim kontekstima, odnosi se na interakciju koja se javlja tokom učenja. Kada informalno učenje zavisi od socijalnog i fizičkog konteksta onda se vrsta učenja koja se javlja zasniva na kontroli situacije učenja. Jedan od načina je određivanje lokusa kontrole interno i u odnosu na učenika (moć učenika) ili eksterno (kontrola od strane spoljnih činioca). Definicija informalnog učenja na osnovu kontrole povezana je sa idejama socijalnog konstruktivizma i kritičke teorije. Socijalni konstruktivizam odnosi se na kontekstualizovanu i socijalno konstruktivnu prirodu učenja (Stroud, 2008). Kritička teorija bavi strukturom vlasti i sukoba u obrazovnim sistemima, opisuje se kao dominantna paradigma u situaciji učenja (Gibs et al., 2007; Stroud, 2008).

Instruktivno- didaktička teorija nastavnika, ili osoblje u muzeju, vidi kao aktivne učesnike, posetioci su pasivni receptori informacija. Institucionalna kultura zasniva se na stručnom znanju ali i na informalnom svakodnevnom znanju. Posrednici su glavni prenosioci znanja, ovaj pristup počiva na tradicionalnim obilascima muzeja. Prednost je što se fokusira na isporuku sadržaja koji se može brzo osmišljavati i memorisati kao činjenice o umetničkom delu ili objektu. Nedostatak se ogleda u tome 
što je znanje izabrano od strane stručnih lica i što se pretpostavlja da će posetioci saznati odabrano i usvojiti, zatim se učenje odvija u maloj sobi za razgovor i posmatra se kao fiskni i kumulativni proces a znanje je neutralno, objektivno i univerzalno. $\mathrm{Ne}$ podržava različite stilove učenja već svi uče na isti način (Gibs et al., 2007).

Zatim postoje teorije koje povezuju detetove individualne potrebe i mogućnosti sa potencijalima i uspesima učenja. Pijažeova teorija rukovanje predmetima prepoznaje kao važan deo obrazovnog rada u muzejima i zahteva dečiju aktivnost na svakom stupnju razvoja. Vigotski akcentuje socijalnu interakciju dok Bruner akcentuje značaj delanja i otkrića u procesu učenja, i poslednja u nizu je teorija Čiksentlmihaljija koji zastupa teoriju optimalnog iskustva gde je sve podređeno unutrašnjoj motivaciji, a glavna odlika je osećaj zadovoljstva, radosti i zanesenosti. Zajedničko svi pomenutim teorijama informalnog obrazovanja je konstrukcija znanja koja je važna za individualnu konstrukciju znanja, za razvoj ličnosti u skladu sa individualnim potrebama i mogućnostima jer se rukovodi stavom da (bez obzira na mnoga zajednička obeležja, kao što su uzrast, pol, socio-ekonomski položaj) ne postoje dve identične ljudske jedinke sa identičnom percepcijom stvarnosti (Piageu, 1990; Vigotsky, 1977; Bruner, 2000 i Csikszentmihalyi, 1990 prema Gajić i Milutinović, 2011).

\section{Konstruktivistički pristup muzejskom učenju}

Konstruktivizam nastaje sedamdesetih godina prošlog veka kada su istraživači uvideli značaj učenja van škole, učionice na izletima, u poseti muzeju, u svojim domovima, u okviru porodice. Ova vrsta učenja je slobodna, nezavisna u fizičkom smislu od konvencionalnih oblika učenja i javlja se u okviru granica formalizovanog školskog sistema. Nastaje paralelno sa informalnim učenjem, zarad opisivanja dinamičnog načina učenja, gde su polaznici aktivno uključeni i uče iz svog okruženja, na prethodna iskustva nadgrađuju nova. Konstruktivizam je zapravo uključivanje novih ideja u već postojeći sistem, mrežu iskustava koje pojedinac poseduje (Stroud, 2008). Konstruktivizam kao teorija učenja sastoji se od dve komponente: teorija obrazovanja i teorija učenja. Teorija obrazovanja zastupa stav da znanje postoji nezavisno od učenika, sastoji se od prolaska kroz intelektualni proces, dok Berkli (Berkeley) kaže da znanje postoji samo u umu znalca. Druga pomenuta komponenta obrazovanja obuhvata uverenje o tome kako ljudi uče ili psihologije učenja, gde postoje dva ekstremna stava. Jedan učenje vidi kao pojedinačnu asimilaciju informacija, činjenica i iskustava do rezultata znanja, gde je učenje zbir svih navedenih tzv "malih koraka". Najpoznatiji je stav da je ljudski um tabula rasa (čiji je glavni zagovornik Džon Lok). Sa druge strane imamo shvatanje učenja na način da um gradi šeme i da se učenje sastoji od izbora i organizovanja od bogatstva senzacija koje nas okružuju, tzv "sintetički” pogled na učenje (Hein, 1995).

Pomenute komponente učenja možemo primeniti na muzejsko učenje. Sistematski predstavljen muzej treba odražavati tačnu strukturu predmeta i sadržaj treba biti predstavljen posetiocu na način koji će doprineti najlakšem razumevanju informacija. Materijal treba biti predstavljen uredno kako bi posetiocima omogućio 
i poslao jednostavnu i jasnu poruku. Konstruktivisti tvrde da je učenje u muzeju zasnovano na ličnim saznanjima i prethodnim iskustvima gledalaca, kao i da je process učenja na osnovu navedenog konstruktivan. U konstruktivističkim muzejima izloženi su predmeti koji omogućavaju posetiocima da donose lične zaključke prema konstruktivističkom principu. Struktura i način posmatranja predmeta ne zavisi od samog sadržaja niti svojstava objekta već od odbrazovnih potreba pojedinca, posetioca. Konstruktivistički muzejski eksponati nemaju fiksne tačke i ciljeve već omogućavaju posetiocu da stvara vlastite veze sa sadržajem i podstiču različite načine učenja. Konstruktivistički muzej nudi više modaliteta učenja, te je tako Gardner (Gardner) video muzej kao vid, model obrazovanja, druga odlika je veza koja se nazire prema poznatim pojmovima i objektima. Eksponati u ovim muzejima podstiču posetioce na povezivanje nepoznatog i novog sa poznatim (Isto).

Konstruktivistička teorija učenja akcentuje učenika, njegova interesovanja, potencijale, te je tako lako uklopljiva sa muzejskim učenjem gde je posetioc u fokusu procesa učenja, kao i uticaj na posetioca na najbolji mogući način, ne na izgled i sadržaj muzeja. Muzeji su mesta od izuzetnog značaja za učenje, zahvaljujući konstruktivizmu možemo ga podrediti potrebama posetilaca i njihovim potencijalima za učenje. Konstruktivističko učenje u muzeju ističe da znanje nastaje u umu učenika koji koristi lične metode učenja, što omogućava muzejima da odgovore na potrebe svih uzrasta učenika, posetilaca (deca, odrasli, starija populacija) (Hein 1995). Pijaže (Piaget) je 1920.god istakao konstruktivizam u učenju govoreći da dete uči tako što aktivno pristupa sklapanju i formiranju strukture znanja (Richter, 1999 in Weber, 2003).

Dirking (Dierking 1991:5) identifikuje 10 karakteristika konstruktivnog učenja:

1. Percepcija je u središtu procesa učenja (čitanje, rasprava, dodirivanje predmeta),

2. Učenje je aktivan proces sa izgrađenim i organizovanim okvirima,

3. Učenje je kognitivni i metakognitivni proces,

4. Ljudi, učenici iste starosne dobi su na različitim razvojnim nivoima,

5. Učenje nije uvek uredno i sekvencijalno,

6. Prethodno znanje, verovanje i iskustvo unapred određuju domete učenja,

7. Učenje se javlja i odvija u fizičkom i društvenom kontekstu, ono promoviše učenje u smislu da ono što vidimo mora da prati ono što čujemo, čitamo,

8. Motivacija je bitna odrednica učenja, utiče na izbor sadržaja koji se uči, kako se nešto uči i na cilj učenja,

9. Učenje zavisi od percepcija učenika, socijalne interakcije, sklonosti, starosti (što nadalje utiče na formiranje individualnog stila učenja),

10. Centralno mesto u procesu učenja zauzima memorija, koja se sastoji iz 3 dela: ultrakratkotrajna memorija, kratkotrajna i dugogodišnja. Gde će dolazne informacije biti smeštene zavisi od važnosti koju učenik pridaje predmetu koji posmatra.

Konstruktivistički pristup muzej predstavlja kao mesto sa mnogo različitih vrsta učenja, fokus je na polazniku a ne na predmetu ili sadržaju. Osoblje muzeja 
radi timski dok se znanje integriše kroz evoluaciju i aktivnost publike. Učenje je aktivan proces i društvena aktivnost. Učenici imaju svoje ideje, vrednosti, iskustva, dok muzejski pedagozi nastoje da obezbede učenje kroz razne izložbe, učenje uz više stilova i niova angažovanosti (Gibs et al., 2007). Konstruktivni pristup učenje vidi kao aktivnu izgradnju znanja kroz interakciju sa društvenim okruženjem (Hooper-Greenhill \& Moussouri, 2000; Kisovar Ivanda, 2014; Milutinović, 2010) i sve se više koristi za shvatanje i organizovanje muzejskih izložbi i programa.

Džordž Hein (George Hein, 1998:131, prema Jelavić, 2014) ističe „Kada je muzej baziran na konstruktivnoj muzejskoj pedagogiji, pedagoški sadržaj je na više načina pristupačan, povezan sa svakodnevnim životom i vođen informacijama o prethodnim znanjima posetilaca“.

\section{Izložbe kao vid pedagoškog muzejskog rada}

Izložba je najčešći oblik muzejskog komuniciranja, stvaralački čin u kom se prikazuju i tumače pojedini fenomeni i znanje o njima u specifičnom odnosu prošlosti i sadašnjosti. Koristi se muzejskim predmetima, služi kao mehanizam za generaciju i selekciju podataka. Glavni nosilac poruke na izložbama je muzejski predmet, kulturno dobro ili komunikacioni objekt. Izložba je specijalizovan vid komuniciranja, ima rok trajanja i ne može se arhivirati, njeno komunikacijsko vreme je sadašnje, daje prikaz znanja ili sadržaja neke teme uzimajći u obzir muzejski ili dostupni izložbeni material i spoznaje koje su do datog trenutka bile poznate. Kao kreativna celina, otvara nove horizonte, upućuje na nova promišljanja odnosa među stvarima (Maroević, 2003). Izložbe su vrsta nekonvencionalne publikacije koje treba da uvedu posetioca da posmatranjem shvati tematiku tokova društveno-istorijskog razvoja. Treba brinuti o cilju, naslovu, sadržini, tematici i funkcionalnosti izložbe. Izložbu treba da prati jasno izlaganje; a namenjena je pre svega mlađoj populaciji (Morine, 1975). Muzejski pedagozi upućuju i objašnjavaju kontekst nastanka i funkciju izloženih predmeta. Izložbe sa određenom tematikom, didaktičke izložbe, radionice su vid edukativnog muzejskog rada (Kuščević, 2015).

Kada je reč o pristupanju izložbenim predmetima, od strane dece, Paris i Merker (Paris \& Mercer prema Isto) ističu dva tradicionalna oblika: pasivnu percepciju i aktivnu konstrukciju. Pasivna percepcija se odnosi na registraciju informacija, a aktivna je temeljni interaktivni proces, polazi od dečijih postojećih znanja, interesa i socijalnih situacija. I treći transakcijski model koji utiče na promenu znanja, uverenja i stavova (Isto).

Eksponati se pokazuju javnosti na izložbama, u publikacijama, elektronskim predstavljanjem ili direktnom komunikacijom sa muzejskim stručnjacima. Izložba sama po sebi nije dovoljna ukoliko nema zainteresovanih posetilaca i ukoliko posete nisu potkrepljene stručnim izlaganjem o izložbi, organizovanjem predavanja, prezentovanja i edukativnih radionica. Predmet na izložbi predstavlja dokaz za deo stvarnosti, muzejska delatnost oslikava kulurno stanje određenog područja (Babić, 2009). Delatnost muzeja počiva na kulturnoj baštini. Kulturna baština predstavlja ži- 
vot određene društvene zajednice i kao takva je predmet mnogih naučnih disciplina. Kako će dete komunicirati sa kulturnom baštinom oslikava dečiji razvojni stupanj, otkriva dečije razvojne karakteristike. Kulturna baština je deo kulture određenog društva i predstavlja vrednost i lepotu koja umnogome produhovljuje ljudski život. Za očuvanje kulturnih baština moguća su tri načina delovanja, vaspitanje i obrazovanje populacije, samoobrazovanje pojedinca $i$ vaspitanje i obrazovanje u vaspitnoobrazovnim ustanovama (Rosić, 2005 prema Kuščević, 2015).

Hein (Hein, 1995, prema Kisovar Ivanda, 2014) objašnjava dva suprotna muzejska koncepta. Prvi kaže da sastavni muzejski sadržaji treba da prikažu pravu strukturu i teme i da budu prezentovani na način koji će posetioci najlakše shvatiti, i drugi, da konstruktivistički muzej nastoji da posetilac iskoristi izložbu za konstrukciju svog znanja i da je znanje samo po sebi konsruktivan proces.

Objekti na izložbi su glavni razlog posete muzeju, kako Veber (Weber, 2003) kaže oni su „kontejneri znanja” koji pored informacija o umetničkim i naučnim fenomenima objedinjuju i kulturno nasleđe. Semper (Semper, 1996, prema Isto) ističe da muzejske izložbe pružaju deci mnogo izbora, gotovo su savršeno mesto za aktivno samoučenje. I kao takve treba da pristupe deci različitog uzrasta, interesa, iskustava, predznanja.

Linhart i saradnici (Leinhart et al., 2002, prema Kisovar Ivanda, 2014) navode rezoluciju i gustinu informacija (fotografije i slike daju pregršt važnih vizuelnih informacija o predmetu), dimenzije (često nemaju naročit značaj, ali su ipak bitne barem na prvi pogled kada posmatrač uoči dimenzije i veličinu izloženog predmeta), izvornost (predmeti su često autentični i vredni) i vrednost (podrazumeva i izvornost i jedinstvenost koje doprinose vrednosti predmeta, iako izvorni predmeti nemaju uvek visoku vrednost) kao odrednice muzejskih predmeta koje određuju značajnost i uticaj izložbe na posetioca.

\section{Radionice kao vid pedagoškog muzejskog rada}

Jedan od vidova obrazovnog rada u muzejima jesu radionice koje imaju za cilj ličnu, psihološku dobit svakog učesnika. Pored raznovrsnih informacija i njihove primene stiču se i određene veštine, svrha radionice je strukturisan scenario, dok se svaka radionica zasniva na pažljivo osmišljenom scenariju sa unapred određenim specijalnim ciljem. Mogu biti usmerene na edukativne, saznajne, metakognitivne, socijalne, komunikacione sposobnosti, ili na razvoj kreativnosti. Radionica podrazumeva učešće većeg broja učenika i njihovu akciju, važno je da nema pasivnih posmatrača, najveći deo radionica valja biti osmišljen u vidu igre. Edukativne radionice pre svega su usmerene na omladinu od predškolskog uzrasta do fakulteta. Odlike radioničarskog postupka pojašnjene su sledećim tvrdnjama: U centru pažnje je lično iskustvo; Učeniku se pristupa kao celovitoj ličnosti i Znanje se ne nameće već se nudi (Pavlović i Lazarević, 2008). 


\section{Saradnja muzeja sa školom}

Nastavnici, kako Rihter navodi (Richter, 1999, prema Weber, 2003) ističe ono što je i danas lako uočljivo, da sve češće izbegavaju otvorene oblike nastave, otvorene nastavne metode a drže se smislenosti poznavanjem činjenica. Međutim, kako je spektar veština za izbor i vrednovanje informacija za izgradnju sopstvenih struktura znanja, za korišćenje i rekonstrukciju znanja, prema potrebama novonastale situacije i sticanje veština za doživotno učenje. Isti autor u okviru SMEC projekta nudi mogućnosti za rad škole i muzeja širom Evrope:

1. Razvoj pitanja za naočigled urođene i precizno određene stvari,

2. Istraživati, što podrazumeva istraživačku sposobnost kod učenika,

3. Razvijati hipoteze, izvući smislene veze među ponuđenim informacijama i proceniti ih,

4. Diskutovati o razvijenim hipotezama, raspravljati o prednostima i nedostacima,

5. Predstaviti svoj rad, istraživanja, pretpostavke drugih, razjasniti ideje i planove,

6. Dokumentovati proces saradnje i rezultate,

7. Razvijati kreativnost pri rešavanju problema.

Muzejske posete treba da igraju važnu ulogu u školskom program, te bi tako one bile zgodna mogućnost za povezivanje muzejskog i školskog rada. Muzej nudi drugačije iskustvo za razliku od školskog okruženja, učionice, pruža mogućnost za razvoj i napredak višestruke inteligencije, daje alternativne mogućnosti za sticanje iskustva za koja učenici moraju angažovati više čula. Ono što dolazi do izražaja su emocionalne reakcije učenika, koje pri školskom radu i učenju često mogu izostati (Chee, 2003).

Zbog zanemarenosti kulturnog nasleđa nužno je poboljšati pedagoški odnos muzeja i škole i kontinuiranim vaspitnim i obrazovnim radom razvijati svest o važnosti kulturnog nasleđa (Pavlović Lazarević, 2008) što se na najefikasniji način može postići delovanjem muzeja preko školskog sistema. Saradnju muzeja sa školskim institucijama treba ostvarivati saradnjom direktora ovih dveju ustanova, saradnjom muzejskog pedagoga sa nastavnim osobljem i pedagoško-psihološkom službom škole kao i saradnjom muzeja sa učenicima u izradi mnogih radova, referata, izveštaja, radionica (Isto). Nosioci saradnje muzeja i škole su nastavno osoblje same škole i pedagoška služba muzeja. Oblici saradnje mogu biti predavanja koja će pripremiti učenike za posetu muzeju, predavanja sa projekcijama u muzeju, pokretne izložbe koje će pratiti nastavni program, izložba u muzeju pripremljena od strane učenika i stručni rad u obradi i prezentovanju školskih zbirki (Stojanović, 1987).

Promene u muzejima traže promenu i identifikaciju potreba za školovanjem, dakle, obrazovne programe treba prilagoditi tako da uvek budu korak ispred prakse (Maroević, 1990). Institucije sa kojima muzeji dolaze u kontakt jesu predškolske ustanove, sve vrste škola, institucije za osmišljavanje slobodnog vremena, institucije za obrazovanje odraslih, fakulteti, akademije (Škarić, 2002). 
Saradnja između škole i muzeja počiva na sledećim tvrdnjama:

1. Muzejsko obrazovne aktivnosti treba da budu integrisane u školski kurikulum.

2. Aktivnosti treba da budu pomno i detaljno planirane.

3. Evaluacija celokupnog procesa saradnje.

4. Planiranje i strukturisanje obrazovnih aktivnosti treba da se zasniva na saradnji školskog i muzejskog pedagoga.

5. Najučinkovitije muzejske aktivnosti treba da budu strukturisane kao nastavni dan jer omogućavaju potpunije i celovitije muzejsko iskustvo (Kisovar Ivanda, 2002; 2009).

Potreba za saradnjom proizlazi iz činjenice da savremena škola ne može pružiti kvalitetno vaspitanje i obrazovanje sa bez drugih kulturnih ustanova, muzeja. Najveća vrednost muzeja u pedagoškom smislu je očiglednost (Rosić, 2005, prema Pavlović Lazarević, 2008) koju valja iskorititi i kada je školsko učenje u pitanju.

\section{Značaj muzeja za dečiji razvoj i učenje}

Muzej nudi deci mogućnost upoznavanja sa svetom i istraživanje različitih stvari, novih ideja i vidika. Deca posećuju muzeje sa širokim spektrom interesovanja (Kisovar Ivanda i Nenadić Bilan, 2015). Predškolska deca pokazuju sledeće karakteristike: energičnost, visok nivo sposobnosti, multiosetljivost, razigranost, veliki broj pitanja, bogatstvo ideja, komunikacijske veštine, samostalnost, tendenciju za sopstvenim pristupima (Piscitelli, Everett \& Weier, 2003, prema Isto). Muzej je poseban, svetao ambijent sa prostranim enterijerom neobične arhitekture i sadržaja koji se razlikuje od školskog i porodičnog ambijenta. Pomenuti autori dečiju reakciju na muzej opisuju kao čuđenje, iznenađenje, osećaj komfora i radoznalosti, interakcijom, visokim nivoom interesovanja, po potrebi fizičkom aktivnošću ili čak frustracijom.

Specifični zahtevi prema muzeju kao instituciji koja ima odlike mesta pogodnog za učenje za decu, Kelli i Graundvoter-Smit (Kelly \& Groundwater-Smith, 2004, prema Isto) vide sledeće faktore:

1. Kognitivni - deci treba dati mogućnost spoznaje osnovnih ideja u vezi sa eksponatima, njihovom strukturom, funkcijom, da postavljaju pitanja, rukuju njima i podsticaj spoznaje uz više čula.

2. Psihofizički - deci je potrebno prijatno okruženje, slobodno kretanje u prostoru bez velikih ograničenja. Svetlost i dizajn arhitekture prostora treba da budu prilagođene uzrastu i psihofizičkim potrebama deteta.

3. Socijalni faktor - deca rade, uče sa prijateljima, u neformalnim situacijama uvek žele prostor za zabavu te tako i prilikom posete muzeju.

4. Emocionalni factor - adekvatnom muzejskom zbirkom deca mogu biti emocionalno angažovana. Neadekvatnom prezentacijom eksponata deca ne mogu uspostaviti emocionalnu vezu sa muzejskim sadržajima, u slučaju neprimerenog sadržaja može se javiti osećaj straha i nelagodnosti. 
Poslednjih godina dolazi do većeg broja programa koje muzej nudi deci, muzej nije samo mesto za razonodu i zabavu, porodičnu šetnju (Munley, 2012) nego mesto koje pruža i nudi širok spektar informacija kojima se može potkrepiti sijaset dečijih interesovanja. Graham (Graham, 2008, prema Isto) opisuje posetu muzeju sledećim koracima: istraživanje, komunikacija, izložba - kreativan izraz i nakon toga, osnov za dalji razvoj.

Šta će deca upamtiti u muzeju zavisi od dotadašnjih poimanja i iskustva kojima raspolažu (Munley, 2012). Prirodni i istorijski muzeji su naročito zanimljivi deci. Odrasli daju spontane odgovore i objašnjenja na dečija pitanja i na taj način pomažu deci u oblikovanju znanja. Akcenat valja staviti na radionice, porodične posete, grupne posete muzeju, interaktivne izložbe kao oblike informalnog učenja za decu mlađeg uzrasta kako bi efekat uticaja na dečiji razvoj bili potpuni. Vođenje kroz stalni sastav ili povremene izložbe, specijalna predavanja, dopuna metodičkih jedinica iz školskog programa, samostalan rad u zbirci, kreativan rad iz sadržaja slobodnih aktivnosti, slobodno vreme rad u muzejskim radionicama, tematske izložbe su načini kojima muzej može privući decu (Kanižaj, 1987).

Savremeni muzej počiva na dinamičnim i interaktivnim odnosima posetilaca, deca dolaze u kontakt sa raznim aspektima stvarnosti koji su van njihovog prostora i vremena u kojem žive. Muzej omogućuje promenu identiteta i olakšava rad sa iskustvom (Kuščević, 2015). Blejk (Blake, 2005, prema Isto) navodi da muzej dozvoljava deci da uveliko istražuju, da budu interaktivni i kreativni. Da bi ovaj cilj bio ispunjen nužno je da se u muzeju omogući učenje na što zabavniji način, dodirivanje izloženih materijala, veći broj izloženih predmeta, minimalna objašnjenja i zapisi uz izložene predmete, izbegavanje dugotrajnog čekanja u redu.

Rend (Rand, 2001: 13-14, prema Isto) ističe listu sa pravima posetilaca, dece: udobnost, dobrodoščica, zabava, socijalizacija, poštovanje, komunikacija, učenje, izbor i kontrola, izazov i poverenje. Muzejski prostor omogućuje raznovrsne načine organizacija socijalnih interakcija dece što podstiče zajedničko dogovaranje i otkrivanje značenja.

Muzej ima brojne prednosti za podučavanje dece jer informalno učenje podstiče unutrašnju motivaciju i želju za saznavanjem. Deca u muzeju mogu iskazati svoju autentičnu radoznalost (Pavlović Lazarević, 2008). Deca u muzej dolaze opuštenija, te je učenje efikasnije. Broj dece koja posećuju muzeje sve je veći, dečiji muzeji su specijalni muzeji i po svojoj koncepciji pripadaju mladoj generaciji muzeja (Cukrov, 2002; Škarić, 2002). Motivacija za posetu može biti želja za obrazovanjem, zabavom, utiscima, ispunjavanjem slobodnog vremena, zadovoljavanjem interesovanja, komunikacijom, društvenim kontaktima (Škarić, 2002).

Deci je naročito potrebna fizička aktivnost, praktično iskustvo, ali i aktivnosti koje angažuju um i ruke (Hein, 1991, prema Hooper-Greenhil \& Moussouri, 2000). 


\section{Zaključak}

Učenje se najčešće vezuje za školu kao formalnu instituciju u kojoj se stiče formalno znanje, neophodno je ukazati na postojanje drugih institucija u kojima se takođe može sticati ne manje važno - neformalno ili informalno znanje. Iz tog razloga ukazali smo na značaj muzeja kao institucije informalnog karaktera, kao mesto sa bogatom pedagoškom delatnošću i potencijalima. Muzej motiviše, budi radoznalost, drži pažnju posetilaca na visokom nivou, obezbeđuje povezivanje dosadašnjih znanja sa nepoznanicom o kojoj svedoči svojom arhitekturom, organizacijom rada, materijalnim predmetima koje poseduje, zaposlenim osobljem. Izuzetan značaj muzeja možemo opravdati bogatstvom informacija i činjenica do kojih posetom muzeju možemo doći. Postoji razlika između tradicionalnih i savremenih muzeja. Tradicionalni muzeji nude podatke o pređašnjem životu, radu, o nekadašnjem učenju i vrednostima, dok, sa druge strane, savremeni muzej podstiče na aktivnost, istraživanje, interakciju i permanentno učenje i usavršavanje.

Kako je muzejski prostor pogodno mesto za informalno učenje (Nenadić Bilan, 2015) cilj rada je predstavljanje muzeja kao informalnog centra za učenje i razvoj, pogodnog za sve uzraste a sa velikim doprinosom kad je reč o sticanju znanja, veština i sposobnosti, o značaju muzeja kada je reč o inoviranju postojećeg znanja i sticanju novih informacija koje se uče i doživljavaju na osnovu ličnog iskustva iskustva posetioca. Nakon istraživanja i procene dostupne literature možemo ukazati na značajnost muzeja kao riznice informacija i njegovom značajnom uticaju kada je reč o razvoju mlađih populacija, na koje deluje i u najvećem slučaju utiče na njihov razvoj i napredak kroz izložbe, radionice, predavanja.

Pedagoški muzejski rad uspešan je ukoliko dovodi do novih znanja, povećava kvalitet veština i sposobnosti i nastoji da sve naučeno „gura“ napred ka daljem razvoju i napretku. Za posetu i učenje u muzeju nije potrebna prethodna priprema već samo volja i motivisanost posetioca da vidi, nauči, da dodje u kontakt sa nečim novim. Ova uloga muzeja je različita u odnosu na školsko učenje i učenje iz knjiga, učenje u muzeju više je praktično nego apstraktno, te kao takvo ostavlja mnogo prostora za dalji naučni rad i istraživanja. Međutim, ne smemo zanemariti značaj saradnje muzeja sa školom kao jednu o značajnijih vaspitno-obrazovnih delatnosti kada je muzejski rad i učenje u pitanju. Saradnja se može odvijati na više načina, organizovanjem zajedniških aktivnosti, izložbi, interaktivnih radionica, predavanja, tribina.

\section{Literatura}

Babić, M. (2009). Muzejske edukativne radionice u program interaktivnih nastavnih i vannastavnih aktivnosti naših škola, Muzeji, 103-119.

Brajčić, M., Kovačević, S. i Kuščević D. (2013). Learning at the Museum, Croatian Journal of Education, 159-178. 
Chee F., M. (2003). Training Teachers fot the Effective Use of Museums, International Journal of Historical Learning, Tesching and Research, 3 (2), 10-16.

Ciolfi, L., Cooke, M., Hall, T., Bamon, L., J. \& Oliva S. (2005). Re-thinking Technology in Museums: Towards a New Understanding of people's Experience in Museums, University of Limerick, Ireland.

Clegg, T., Gardner, C., Williams, O., \& Kolodner J. (2006, June). Promoting learning in informal learning environments. In Proceedings of the 7th international conference on Learning sciences, International Society of the Learning Sciences, 92-98.

Cukrov, T. (2002). Dečiji muzeji, Iz muzejske teorije i prakse, 33 (1-2), 98-100.

Davis, P. (2004). Recognising and Valuing Non-Formal and Informal Learning: the Role of Universities, Adult Education and Museums, Museums and Galleries as Learning as Learning Places, 1-5.

Eddisford, S. (2009). Learning in Smaller Museums, 1-9, Retrieved 14.02.2017. from: http://www.aim-museums.co.uk/downloads/d892a895-dd7d-11e1-bdfc001999b209eb.pdf

Gajić, O. i Milutinović J. (2011). Vaspitanje umetnošću-emancipatorni potencijal u društvu znanja, Tekst je rezultat rada na projektu Kvalitet obrazovnog sistema Srbije u Evropskoj perspektivi, br.179010 (2011-2014).

Gibbs, K., Sani, M., \& Thompson J. (2007). Lifelong learning in museums: a European Handbook. Edisai.

Hawkey, R. (2004). Learning with Digital Technologies in Museums, Science Centres and Galleries Retrieved 10.02.2017. from: https://telearn.archives-ouvertes.fr/hal00190496/document

Hein, G. (1995). The Constructivist Museum, Journal for Education in Museum, 16, 1-8.

Hooper-Greenhill E. \& T. Moussouri (2000). Researching Learning in Museums and Galleries 1990-1999: A Bibliographic Review, Research Centre for Museums and Galleries.

Jelavić, Ž. (2014). Edukativni programi uz projekt Svijet igračaka. Etnološka istraživanja, (18/19), 279-283.

Kanižaj, Lj. (1987). Obrazovanje u muzeju: stanje u muzejima Jugoslavije, Muzejski dokumantacioni centar, Zagreb, 1-4.

Kisovar Ivanda, T. i Nenadić Bilan D. (2015). Interrelationship Between a Childs, Early Childhood Education, International Research Report, Sopron, Hungary.

Kisovar Ivanda, T. (2014). Modeliranje muzejskih sadržaja i interakcijske aktivnosti učenika u muzejskom okruženju, Školski Vjesnik 63 (1-2), 53-69.

Kisovar Ivanda, T. (2009). Uloga didaktičkog struktuiranja muzejskih sadržaja u stvaranju školskog kurikula, Magistra Iadertina 4 (4), 70-81.

Kušćević, D. (2015). Kulturna baština- poticatelj dječijeg razvoja (likovni aspekt), $R a$ sprave i članci, 479-491.

Maroević, I. (2003). Muzejska izložba- muzeološki izazov, Informatika Muzeologija, 34 (3-4), 13-18.

Maroević, I. (1990). Promjene u muzejima i potrebe za obrazovanjem, Iz muzejske teorije i prakse, 1-2, 63-65. 
Milutinović, J. (2010).Učenje u muzeju, Povijest u nastavi 2 (26), 217-229.

Morine, T. (1975). Muzej i škola, 132-138, Preuzeto 11.02. 2017. sa sajta: file:///C:/ Users/b/Desktop/17_13_Tefik_Morina.pdf

Munley, E., M. (2012). Early Learning in Museums, Literature Review Smithsonian Institution, MEM \& Associates, 1-27.

Navarro, O. (2012). History and Education as Bases for Museum Legitimacy un Latin American Museums: Some Comments FOR A Discussion from a Critical Museology Point of View, 28-33, Retrieved 02.02.2017. from:

https://digilib.phil.muni.cz/bitstream/handle/11222.digilib/131353/2_MuseologicaBrunensia_1-2012-1_9.pdf? sequence $=1$

Nenadić Bilan, D. (2015). Predškolsko dijete i baština- Istraživanje u muzeju, Rasprave $i$ članci, 492-503.

Pavlović Lazarević, G. (2008). Da li mogu opet da dođem?, Edukativna radionica u pedagoškom muzeju, preuzeto 13.02.2017. sa sajta:

http://www.anthroserbia.org/Content/PDF/Articles/5fcea7a14f004fc3a42bd31f30cafd66. pdf

Škarić, M. (2002). Uloga muzejskih publikacija u edukaciji djece. Informatica Museologica, 32(3-4), 73-75.

Stojanović, L. (1987). Oblici suradnje muzeja i osnovnih škola. Informatica Museologica, 18(1-4), 31-32.

Stroud, S., N. (2008). Teaching and Learning in a Museum: Examining the Role of Attitudes Toward Science, Knowledge of Science and Participatory Learning in an Astronomy Intership for High School Students, School of art and sciences Columbia University.

Trskan, D. (2003). Pedagogyc Activities of Museums in the Republic Slovenia, International Journal of Historical Learning, Tesching and Research, 3 (2), 48-54.

Weber, T. (2003). Learning in schools and learning in museums: which methods best promote active learning?, Retrieved 11.01.2017 from:

http://www.museoscienza.org/smec/manual/02_general\%20chapters_all\%20languages $/ 02.3$ _\%20learning\%20in $\% 20$ schools $\% 20$ and $\% 20$ museums_en.pdf

\title{
PEDAGOGICAL POTENTIAL OF MUSEUM - MUSEUM AS A CENTER OF EDUCATION AND LEARNING
}

\author{
Aleksandra Milanović \\ University of Niš, Pedagogical Faculty Vranje
}

\begin{abstract}
This paper analyzes the importance of museums for educational work. The museum, on first sight seen as the place for spending free time at, has great importance and contribution to educational work with both the young and the older generations. The most common form of going to the museum are the guided tours of groups of stu-
\end{abstract}


dents organized by teachers, mainly native language teachers or teachers of fine arts. In this work we tried to point out the importance of the modern theory of pedagogical work at the museum (active learning, constructive theory, instructively-didactic theory, socio-constructivist theory, critical theory). Then we approached constructivist access to the museum learning. In the second part we have represented aspects of pedagogical work in a museum. The first aspect of pedagogical work in the museum are the exhibitions. They are always organized according to certain subjects and with a specific purpose, which is not strictly defined what visitors will pay the most attention to and where on the other hand provides a number of unique adventure and experiences. The exhibition is the perfect place to connect past and present, if the main feature of the exhibition is historic moment. Also, it is the ideal way for communication of the visitors with exposed museum material and discussion with the museum staff as well as other visitors. Workshops, as another aspect of the educational work of the museum, provide an opportunity to acquire skills and interact with the other members of the group. We have also tried to point out the importance of the cooperation between museums with educational institutions at all levels, for which the compliance of the museum and school programs is important. Cooperation of museum with educational institutions contributes to the whole social development, but also better quality development of visitors' personality, mostly children.

Keywords: museum, learning, modern theories, constructivism, exhibitions, workshops, cooperation

\section{Citiranje članka:}

Milanović, A. (2018). Pedagoški potencijal muzeja - muzej kao centar obrazovanja i učenja. Godišnjak za pedagogiju, 3(2), 73-89. 
